\title{
Kecanduan Game Online dan Empati pada Mahasiswa
}

\begin{abstract}
Abstrak
Artikel INFO

Diterima:30 Okt 2019

Direvisi :28 Jan 2020

Disetujui: 05 Mei 2020

DOI:

http://dx.doi.org/10.24014/

jp.v14i2.8168

Empati merupakan kemampuan seseorang untuk mengenal dan memahami emosi, pikiran serta sikap orang lain. Salah satu hal yang mempengaruhi empati seseorang adalah kecanduan game online. Penelitian ini bertujuan untuk mengetahui apakah tingkat kecanduan game online akan mengurangi empati pada mahasiswa. Sampel penelitian berjumlah 120 Mahasiswa Fakultas Sains dan Teknologi UIN Suska Riau yang menggunakan teknik pengampilan sampel yakni purposive sampling. Instrument dalam penelitian ini yaitu skala kecanduan game online yang merupakan hasil modifikasi dari skala Chen dan Chang dan hasil adaptasi dan modifikasi skala empati dari skala Davis. Hasil analisis korelasi product moment dari Pearson diperoleh ada hubungan yang negatif antara kecanduan game online dengan empati pada mahasiswa artinya semakin tinggi durasi jam seseorang bermain game online maka semakin kurang tingkat empati seseorang.
\end{abstract}

\author{
Rahmi Kurniawati, Harmaini \\ Fakultas Psikologi Universitas Islam Negeri Sultan Syarif Kasim Riau \\ email:harmaini@uin-suska.ac.id
}

Kata Kunci : Empati, Kecanduan, game online

\section{Online Games Addiction and Empathy among Undergraduate Students}

\begin{abstract}
Empathy is a person's ability to recognize and understand the emotions, thoughts and attitudes of others. One thing that affect one's empathy is an addiction to online games. This study aims to determine whether the level of online gaming addiction will reduce empathy in students. The research subjects were 120 Undergraduate students of the Faculty of Science and Technology of UIN Suska Riau, got using purposive sampling. The instrument in this study is the online game addiction scale which is a modification of the Chen and Chang scale and the result of the adaptation and modification of the empathy scale of the Davis scale. Pearson correlation analysis results got there is a negative relationship between online game addiction with empathy for students means that the higher the duration of a person's time playing online games, the less the level of one's empathy.
\end{abstract}

Keywords: Empathy, Addiction, online games

\section{Pendahuluan}

Mahasiswa dapat didefinisikan sebagai individu yang sedang menuntut ilmu ditingkat perguruan tinggi, baik negeri maupun swasta atau lembaga lain yang setingkat dengan perguruan tinggi (Siswoyo 2007). Mahasiswa dinilai memiliki tingkat intelektualitas yang tinggi, kecerdasan dalam berpikir dan perencanaan dalam bertindak. Berpikir kritis dan bertindak dengan cepat dan tepat merupakan sifat yang cenderung melekat pada diri setiap mahasiswa, yang merupakan prinsip yang saling melengkapi. Goleman (2007) keberhasilan seseorang dalam kehidupan tidak hanya ditentukan oleh kecerdasan inteligensi, inteligensi tidak dapat bekerja dengan sebaik-baiknya tanpa kecerdasan emosional. Kecerdasan emosional yang tinggi diperlukan agar mampu mengendalikan diri dan orang lain. Dengan mengutamakan kepentingan umum, dari pada perorangan dan golongan. 
Salah satun bentuk dari kecerdasan emosional adalah yaitu kompetensi emosional yang meliputi kompetensi individual dan sosial (Aulya Purnama \& Wahyuni, 2018). Menurut Goleman (2007) salah satu komponen kompetensi sosial yaitu berempati terhadap orang lain. Nurhayati (2012) empati merupakan suatu kemampuan yang dimiliki oleh seseorang untuk dapat memahami perasaan dan pikiran orang lain tanpa harus melibatkan secara nyata dalam perasaan dan pikiran orang tersebut. Empati juga memberikan kontribusi terhadap perkembangan moral mahasiswa, walupun empati dianggap sebagai keadaan emosional, sering kali empati memiliki komponen kognitif yaitu kemampuan melihat keadaan psikologis dalam diri orang lain, atau yang disebut dengan mengambil perspektif orang lain (Batson, C. D., Eklund, J.H., Chermok, V.L.,Hoyt, J. L., \& Ortiz, B. G. ,2007).

Empati merupakan kemampuan untuk merasakan keadaan emosional orang lain, merasasimpatik, danmencobamenyelesaikan masalah, dan mengambil perspektif orang lain (Baron \& Bryne 2005). Menurut Keen (2007) empati adalah mengenali perasaan orang lain dan memahami pengalaman emosional orang lain tanpa berpartisipasi didalamnya. Empati adalah keterlibatan proses psikologis yang membuat seseorang memiliki fellings lebih kongruen dengan situasi diri sendiri (Hoffman, 2000).

Eisenberg (2000) berpendapat bahwa empati merupakan respon afektif yang berasal dari pemahaman kondisi emosional orang lain, yaitu apa yang sedang dirasakan oleh orang lain pada waktu itu. Menurut Davis (dalam Taufik, 2012), membagi aspek empati dalam empati bagian yakni, Perspective taking, Fantasy, Emphatic concern, Personal distress. Keempat aspek ini merupakan aspek yang mengukur empati pada mahasiswa.

Mahasiswa mestinya mampu mengenali dirinya sendiri dan secara bersamaan mengakomodasi sudut pandang dan kepentingan orang lain. (Setyawan, 2001). Kemampuan empati, pada akhirnya merupakan salah satu alternatif pemecahan yang harus dikembangkan oleh mahasiswa (Fauziah, 2014). Sejauh mana pentingnya empati seperti yang dikemukakan oleh
(Hoffman, 2000) empati sangat penting karena memiliki kontribusi dalam perkembangan moral. Menurut (Batson \& Ahmad, 2009) empati dapat menimbulkan keinginan untuk menolong.

Saputra (2016) menjelaskan seiring dengan berjalannya waktu, kepedulian orang terhadap orang lain dan lingkungan disekitar menurun. Dapat dikatakan bahwa manusia sekarang menjadi lebih menggunakan konsep hidup menyenangkan diri sendiri dahulu baru orang lain, sehingga mengakibatkan manusia menjadi makhluk yang individual (Roughgarden \& Tardos, 2002). Dawkins $R$ yang dikutip oleh Het J. (Hey, 2005) menyebutkan keadaan ini dengan istilah gen egois. Gen egois yang dimaksud adalah sesuatu yang bisa membuat salinan dirinya sendiri. Dawkins (dalam Taufik, 2012). mengajukan gagasan replikator lain, yang bukan berada di sel kita melainkan menghuni akal budi manusia yaitu meme. Meme adalah aneka unit gagasan dan budaya manusia yang bisa menular, berlipat ganda, mempengaruhi perilaku manusia, serta berperilaku evolusioner seperti gen yang saling bersaing untuk bisa bertahan hidup dan berbiak. Gen dan meme membentuk serta mengendalikan tubuh dan perilaku dan dunia. Dalam kondisi seperti ini, empati diperlukan untuk menghilangkan ketidakpedulian pada orang lain.

Menurut Hoffman (2000) mengemukakan bahwa faktor-faktor yang mempengaruhi empati seseorang yaitu, sosialisasi, Mood dan feelling, Proses belajar dan identifikasi, Komunikasi dan bahasa, Pengasuhan, Lingkungan. Selain itu faktor lain yang mempengaruhi empati seseorang menurut Borba (2008) yaitu permainan (game online), game online bisa memberikan pengaruh buruk bagi kepribadian karena menyodorkan pelecehan, kekerasan, dan penyiksaan.

Fenomena menurunnya perilaku empati mahasiswa terhadap orang lain selaras dengan penelitian yang dilakukan Madina (2014) terhadap 215 mahasiswa $(56,86 \%)$ di salah satu Universitas Gorontalo menunjukkan bahwa mahasiswa memiliki perilaku empati yang sangat rendah. hal ini dipengaruh dari berbagai sumber yang mudah didapat, seperti televisi, film, permainan (game 
online), internet yang memberikan pengaruh buruk bagi kepribadian peserta didik karena menyodorkan pelecehan, kekerasan, dan penyiksaan (Borba, 2008). Perkembangan teknologi yang sangat pesat semakin memudahkan manusia untuk memperoleh hiburan dan komunikasi dengan orang yang jauh (Prasatya, 2015). Teknologi digital masa kini yang semakin canggih menyebabkan terjadinya perubahan besar dunia. Manusia telah dimudahkan dalam melalukan akses terhadap informasi melalui banyak cara, serta dapat menikmati fasilitas dari teknologi digital dengan bebas, namun dampak negatif muncul pula sebagai mengancam. Tindak kejahatan mudah terfasilitasi, game online dapat merusak mental generasi muda, pornografi, dan pelanggaran hak cipta mudah dilakukan, dan lain-lain (Setiawan W, 2013)

Salah satu bentuk perkembangan teknologi saat ini adalah gadged. Gadged dilengkapi dengan berbagi aplikasi yang dapat memudahkan penggunaanya seperti aplikasi game online Hornby (2000). Game online semakin populer dan menarik bagi banyak kalangan dari hari kehari. Kemenarikan game online tidak hanya berlaku sesaat tetapi menimbulkan perilaku yang kompulsif bagi penikmatnya. Tingkah laku ini menimbulkan istilah kecanduan. Kecanduan adalah suatu gangguan yang bersifat kronis dan kompulsif berulang-ulang untuk memuaskan diri pada aktivitas tertentu (Soetipjo, 2007). Freeman (2010) menyampaikan bahwa game online merupakan permainan yang dimainkan melalui koneksi internet.

Pada individu yang memiliki karakteristik interaksi rendah atau keterampilan sosialnya buruk maka akan sulit untuk membangun relasi didunia nyata sehingga individu tersebut akan beralih pada usaha membangun relasi didunia maya melalui permainan game online (Young, K. 2009). Ketika individu mengalami kesulitan dalam perkembangannya, maka untuk mengatasi hal tersebut penggunaan internet menjadi lebih penting dibandingkan apa yang dilakukan orang lain pada umumnya, karena aktivitas online dapat memperluas dan memperkuat jaringan sosial mereka (Smahel, 2012). Akan tetapi, aktivitas seperti ini dapat berbahaya jika media sosial adalah fokus utama dari kehidupan mereka sebagai sarana untuk mendapatkan dukungan sosial dan hubungan interpersonal dikarenakan dapat mengarah pada perilaku penyalahgunaan internet berupa ketergantungan pada media tersebut.

Menurut Yee (2002) kecanduan game online adalah suatu perilaku tidak sehat yang berlangsung terus menerus yang sulit diakhiri oleh individu yang bersangkutan. Perilaku yang tidak sehat dapat merugikan diri individu tersebut dan perilaku seperti ini terlihat pada pemain game online. Kecanduan juga dikenal dengan istilah ketergantungan. Ghodse (2002), ketergantungan ditandai dengan respon perilaku yang selalu menyertakan keharusan terus menerus atau periode untuk mengalami dampak psikis dan kadang-kadang menghindari ketidak nyamanan. Kecanduan didefinisikan sebagai suatu perilaku tidak sehat atau merugikan diri sendiri yang berlangsung terus menerus yang sulit diakhiri individu bersangkutan (Yee, 2002).

Kecanduan game online merupakan satu jenis bentuk kecanduan yang disebabkan oleh teknologi internet atau yang lebih dikenal dengan internet addictive disorder. Internet dapat menyebabkan kecanduan, salah satunya adalah berlebihan dalam bermain game online. (Soetipjo, 2007). Seseorang yang mengalami kecanduan bisa menggunakan waktu 2-10 jam per minggu (Kusumadewi, 2009) bahkan 39 jam dalam seminggu, jadi rata-rata perhari yaitu kurang lebih 5 jam (Young, 1998) atau rata-rata 2025 jam dalam seminggu (Chen \& Chou; Chou \& Hsiao, dalam Chou, etal., 2005) untuk memainkan game online. Akibatnya, pecandu game online mengalami gangguan berupa masalah relasi dengan sesama (Chen \& Chang, 2008).Ketergantungan ditandai dengan respon perilaku yang selalu menyertakan keharusan terus menerus atau periode untuk mengalami dampak psikis dan kadang-kadang menghindari ketidak nyamanan.

Suler (1996) menyatakan pengguna internet dapat di golongkan menjadi dua golongan. Pertama, pengguna internet yang menggunakan internet secara sehat, artinya golongan ini mampu memadukan kehidupan nyata dengan dunia cyberspace. Individu- 
individu tersebut membicarakan aktivitas online dengan keluarga dan teman-teman, menggunakan identitas, minat, dan keahlian yang sebenarnya dalam komunitas online, menelpon dan bertemu langsung dengan orang yang dikenal melalui aktivitas online, atau bertemu dengan teman yang dikenal dalam dunia maya melalui internet. Kedua, penguna internet yang menggunakan internet secara tidak sehat. Pada bagian ini individuindividu memisahkan antara kehidupan

Bermain game online dengan fasilitas internet membuat seseorang merasa senang karena mendapatkan kepuasan psikologis. Kepuasan yang diperoleh dari game membuat mahasiswa semakin betah menggunakan game online, selain itu penampilan game yang semakin memukau dan sistem suaranya yang benar-benar seperti nyata membuat mahasiswa akan semakin tertarik menekuni dan menjelajahi dunia game online. bagi mahasiswa yang berlebihan bermain game online dapat menghabiskan sebagian waktunya hanya untuk bermain game dan mahaiswa tidak menghiraukan aktivitas lain yang penting baginya, seperti makan, belajar, bahkan waktu untuk bersosialisasi dengan teman maupun keluarga akan sangat berkurang (Fitri, 2016).

Kuss, dkk. (2012) menjelaskan bahwa kecanduan game online berhubungan dengan berbagai macam simptom psikopatologis dan psikiatri dengan berbagai macam dampak negatif. Didalam DSM-V (2013) kecanduan game online merujuk pada penggunaan internet secara berlebihan dan terus menerus didalam permainan, dengan banyak pemain lain, yang menyebabkan distress yang didindikasi oleh 5 atau lebih kriteria selama masa 12 bulan. Kriteris diaagnostika tersebut antara lain keasikan bermain game, tanda-tanda menarik diri, toleransi menghabiskan banyak waktu untuk bermain, kurang kontrol diri, kehilangan ketertarikan, tetap menggunakan walupun tau dampak negatifnya, menipu, modifikasi mood, dan kehilangan hubungan, pekerjaan, dan beberapa aspek penting dalam hidup.

Game online merupakan fenomena diberbagai kalangan dari yang tua sampai yang muda, begitu juga yang terjadi pada mahasiswa. Berdasarkan hal inilah peneliti merasa perlu melakukan analisa guna meninjau sejauh mana kecanduan game online yang dilakukan mempunyai korelasi terhadap empati pada mahasiswa UIN Suska Riau.

\section{Metode}

\section{Subjek}

Subjek dalam penelitian ini adalah mahasiswa fakultas Sains dan Teknlog UIn Suska Riau laki-laki berjumlah 115 orang $(9,8 \%)$, sedangkan sampel perempuan berjumlah 5 orang $(4,2 \%)$. Rentang usia sampel pada penelitian adalah 20-40 tahun. Berdasarkan kategorisasi diketahui bahwa sebanyak $41 \%$ sampel penelitian adalah berusia 22 tahun.Teknik penentuan sampel ini berdasarkan kriteria sebagai sumber data ( Sugiyono, 2011), yaitu : (1)mahasiswa Sains dan Teknologi UIN Suska Riau yang berusia 18-40 tahun menurut Hurlock, 1990, (2) Bermain game online lebih dari 3 atau 4 jam perhari. Menurut Chou \& Hsiai (2000) individu yang bermain game online 3-4 jam perhari dikategorikan sebagai pecandu game online dan (3) Bermain game online baik di warnet ataupun di rumah. Instrument penelitian yang dgunakan adalah skala kecanduan game online dan skala empati.

\section{Pengukuran}

Model skala kecanduan game online diukur dengan menggunakan skala dari Chen dan Chang (2008) yang diadaptasi dari skala kecanduan game online yang digunakan oleh Ferdy (2014). Sedangkan model skala empati yang disusun dan dimodifikasi berdasarkan teori Davis (1983) dengan menambahkan beberapa aitem yang sesuai dengan aspek-aspek yang telah dikemukakan yaitu Perspective taking, Fantasy, Emphatic concern, Personal distreesmenggunakan skala likert. Skala likert digunakan untuk mengukur sikap, pendapat, dan persepsi seseorang atau sekelompok orang tentang fenomena sosial (sugiyono,2011). Kedua skala menggunakan model Likert untuk mengukur sikap, pendapat, dan persepsi seseorang atau sekelompok orang tentang fenomena sosial (Sugiyono,2011) 


\section{Analisis Data}

Teknik analisis data yang digunakan dlam penelitian ini adalah teknik korelasi product moment oleh pearson yang bertujuan untuk mengetahui hubungan dua variabel (Arikunto, 2006). Analisis yang dilakukan menggunakan bantuan komputerisasi dengan aplikasi program Statistical of Package for social (SPSS) 17.0 for Windows.

\section{Hasil}

Berdasarkan durasi bermain game online dapat dilihat gambaran persentase sampel sebagai berikut : Dari tabel di atas, maka dapat diketahui bahwa persentase yang paling besar terletak pada durasi 5 jam/hari dengan persentase $33,3 \%$. 4jam/jari sebanyak 30,3\%. dan 6 jam/hari sebesar $10 \%$.

\section{Tabel 1Sampel Penelitian Berdasarkan Durasi Jam/Hari}

\begin{tabular}{cccc}
\hline No & Durasi & Jumlah & Persentase \\
\hline 1 & 4 jam/hari & 37 & 30,3 \\
2 & 5 jam/hari & 40 & 33,3 \\
3 & 6 jam/ hari & 13 & 10,8 \\
4 & 7 jam/ hari & 5 & 4,1 \\
5 & 8 jam/ hari & 11 & 9,1 \\
6 & 9 jam/ hari & 2 & 1,6 \\
7 & 10 jam/ hari & 12 & 10 \\
\hline Total & & $\mathbf{1 2 0}$ & $\mathbf{1 0 0 \%}$ \\
\hline
\end{tabular}

Berdasarkan analisis korelasi pearson product moment menunjukkan nilai signifikansi dalam penelitian sebesar $-0,000$ lebih kecil dari $0,01(0,000 \leq 0,01)$ dengan nilai $r$ sebesar $-0,476$. Hal ini menunjukkan bahwa terdapat hubungan yang negatif antara kecanduan game online dengan empati pada mahasiswa.

\section{Pembahasan}

Hasil penelitian, menunjukkan bahwa empati dalam penelitian ini adalah negatif, sehingga empati yang negatif membuat mahasiswa menjadi kurang dapat memahami dan merasakan apa yang terjadi dilingkungan sosialnya. Kurangnya Empati dipengaruhi oleh berbagai macam faktor, dalam penelitian ini ditemukan bahwa kemajuan teknologi seperti game online memiliki peranan besar, yang akhirnya menyebabkan seseorang mementingkan diri sendiri, menjadi makhluk yang individual, sehingga menyebabkan empati mereka menjadi berkurang.

Hoffman, (2000) menyatakan, faktor kepribadian berpengaruh terhadap tingkat empati seseorang. Pribadi yang tenang dan sering berintropeksi diri dipastikan akan memiliki kepekaan yang tinggi ketika berbagi dengan orang lain. Kepekaan ini yang kemudian menumbuhkan empatinya terhadap orang lain. Borba (2000) menyatakan bahwa permainan game online mempengaruhi empati seseorang yaitu memberikan pengaruh buruk terhadap perilaku seseorang. Artinya dengan bermain game online seseorang Penelitian yang dilakuakn Young (2009) yang menemukan bahwa individu yang mengalami kecanduan internet terutama game online mempunyai permasalahan dalam relasi sosialnya. Menurut Yee (2006) memulai relasi didunia maya lebih mudah daripada dikehidupan sosial nyata.

Hasil analisis Kecanduan game online pada mahasiswa Sains dan Teknologi UIN Suska Riau berada pada kategori sedang. Begitu juga dengan empati pada mahasiswa Sains dan Teknologi berada pada kategori sedang. terlihat pada persentasi yang terdapat pada hasil analisis pengkategorian menujukkan tingkat kecanduan dan empati yang sedang, artinya, hasil analisis tersebut menunjukan bahwa mahasiswa Sains dan Teknologi dapat mengontrol waktu dalam bermain game online, serta 
mampu mengimbangi rasa empati terhadap sesama. hal Ini dibuktikan dengan penelitian yang dilakukan oleh Young, (1998, dalam Pratiwi, 2012), individu yang mengalami kecanduan internet terutama game online mempunyai permasalahan dalam relasi sosialnya, Young menemukan bahwa $53 \%$ individu yang mengalami kecanduan game online mempunyai permasalahan dalam relasi sosial. Memulai relasi didunia maya lebih mudah dibandingkan dengan kehidupan sosial nyata. Pada individu yang memiliki karakteristik interaksi rendah atau keterampilan sosialnya buruk maka akan sulit untuk membangun relasi di dunia nyata sehingga individu tersebut akan beralih pada usaha membangun relasi didunia maya melalui permainan game online.

Hasil penelitian yang menunjukkan mayoritas adalah laki-laki, 115 laki-laki dan 5 orang perempuan. Fenomena ini menurut Imanuel (2009) bahwasannya lakilaki lebih cenderung bermain game online dibandingkan perempuan. Hal ini juga didukung oleh penelitian Awareness Network (dalam Blais, Craig, Pepler, Connolly, 2007) mahasiswa laki-laki adalah bemain game online, adapun laki-laki sebanyak $85 \%$ jauh dibanding perempuan hanya $68 \%$. Hal ini dikarenakan laki-laki memilih game online karena memiliki variasi bermain dengan tingkat kesulitan, cepat gerak, dan terdapat jaringan didalam permainan game online sehingga dapat dimainkan bersama temantemannya, sedangkan perempuan lebih memilih permainan dengan karakteristik artististik atau ekspresi diri yang dinilai lebih mudah dimainkan. Rata-rata alasan subjek bermain game online disebabkan karena menghilangkan stress. Hal tersebut dapat saja terjadi karena bermain game online merupakan aktivitas yang menyenangkan, banyak bertemu dengan kawan baru khususnya sesama pemain game.

Seseorang yang mengalami kecanduan akan mengalami gejala-gejala Withdrawal (merasa stress, tidak enak, bahkan marah) jika menghentikan kegiatan tersebut (Soetjipto, 2007) Kecanduan game online ditandai oleh sejauh mana pemain game online bermain secara berlebihan yang dapat berpengaruh negatif bagi sipemain game tersebut (Weinstein, 2010) kebiasaan bermain game juga membuat mereka terasing dari lingkungannya. Bermain game umumnya dilakukan sendirian, dan itu dilakukan dalam waktu yang cukup lama. Semakin kecanduan terhadap game, semakin sedikit pula waktu yang tersedia untuk berkomunikasi dengan teman-teman seusianya (Prayoga, 2009)

Sedikitnya ada 4 unit dampak kecanduan game online 1) Compulsion (Kompulsif atau dorongan untuk melakukan secara terus menerus), merupakan suatu dorongan atau tekanan kuat yang berasal dari dalam diri sendiri untuk melakukan suatu hal secara terus menerus bermain game. 2) Withdrawal (Penarikan Diri), seseorang yang kecanduan game akan merasa tidak mampu untuk menarik diri atau menjauhkan diri dari halhal yang berkenaan dengan game. 3) Tolerance (Toleransi), biasanya toleransi ini berkenaan dengan jumlah waktu yang digunakan atau dihabiskan untuk melakukan sesuatu yang dalam hal ini adalah bermain game. 4) Interpersonal and health-related problems (masalah hubungan interpersonal dan kesehatan), pecandu game onlione cenderung untuk tidak menghiraukan bagaimana hubungan interpersonal yang mereka miliki karena mereka hanya terfokus pada game saja (Theodora, 2012). Inilah mengapa empati pada mahasiswa diperlukan jangan sampai berkurang bahkan bisa hilang

Seseorang yang kecanduan game online akan mengorbankan waktu dan uangnya hanya untuk bermain game didepan monitor, atau didepan layar HP. Mereka kurang peduli dengan lingkungan sekitar, mereka tidak mau tau apa yang dilakukan orang lain. Dimana rasa ketidak pedulian dengan lingkungan ataupun keadaan diri sendiri merupakan salah satu indikator dari empati yang rendah. pada kecanduan game online ditemukan umur 22 tahun memiliki mean yang lebih tinggi dibandingkan umur yang lainnya.

Menurut Griffiths (2007), individu yang mengalami kecanduan game, konflik antara lingkungan dan psikologis. Bermain game online secara berlebihan akan mengakibatkan masalah fisik, sosial, pekerjaan, atau psikilogis yang kerap kali timbul disebabkan karena permainan game online yang berlebihan. penyebab dari seringnya bermain game online 
bisa menurunkan prestasi belajar, hubungan dengan teman dan keluarga menjadi renggang karena waktu bersama mereka menjadi jauh berkurang. Pergaulan hanya dengan bermain game online menyebabkan mahasiswa menjadi makhluk individual.

Memulai relasi didunia maya memang lebih mudah dibandingkan dengan kehidupan sosial nyata. Kemudahan ini mengakibatkan mahasiswa sebagai bagian dari masyarakat menjadi masyarakat cyber berakibat hilangnya batas-batas sosial. Pada era globalisasi dan abad virtual seperti sekarang, banyak konsep sosial seperti struktur sosial, interaksi sosial, integrasi, dan solidaritas kelompok menjadi kehilangan realitas konkretnya (Nasrullah, Rulli. 2001). Teknologi mendorong budaya technopoly yaitu suatu budaya dimana masyarakat di dalamnya mendewakan teknologi dan teknologi tersebut mengontrol semua aspek kehidupan (Straubhaar, 2010).

Hoffman, (2000) tinggi rendahnya empati seseorang dapat dipengaruhi beberapa hal diantara sosialisasi, sosialisasi dapat mempengaruhi empati melalui permainanpermainan yang memberikan peluang kepada seseorang untuk mengalami sejumlah emosi, Perubahan pola perilaku dari sisi kepribadian seorang pemain game online terlihat dengan jelas dari bagaimana perubahan konstan emosinya yang tidak menentu, kadang tenang, kadang meluap-luap (Kaplan, A. M., and Haenlein, Michael, 2010). Hal ini dipicu oleh keadaan-keadaan yang terjadi dalam permainan, misalnya kalah dalam pertarungan melawan monster dalam game, dibunuh karakter pemain lain, kehilangan koin dalam game karena ditipu pemain lain, dan lain sebagainya. Rata-rata para pemain menunjukkan reaksi emosi yang sama ketika bermain dan mengalami keadaan-keadaan tersebut (Gerry F. Kapoh, 2015).

Faktor lainnya yaitu situasi atau tempat, pada sistuasi tertentu seseorang dapat berempati lebih baik dibandingkan situasi yang lainnya. Hal ini disebabkan tempat dan situasi yang berbeda pula. Suasana yang berbeda inilah yang dapat meninggi rendahkan empati seseorang. Keadaan tersebut menggambarkan bahwa selain faktor kondisi dalam diri atau karakteristik kepribadian individu ada faktor lain yang mempengaruhi empati, seperti kemampuan kognitif untuk mengambil perspekrif orang lain dan kecenderungan untuk memperhatikan orang lain yang dapat menimbulkan empati emosioanl (Taufik, 2012)

\section{Kesimpulan}

Berdasarkan hasil dari analisis data dalam penelitian dan pembahasan di atas dapat disimpulkan bahwa terdapat hubungan yang negatif antara kecanduan game online dengan empati pada mahasiswa Fakultas Sains UIN Suska Riau, artinya semakin tinggi kecanduan game online maka semakin rendah empati pada mahasiswa. Mahasiswa cenderung memiliki empati yang rendah, dan kecanduan game online yang tinggi . Hasil penelitian ini menunjukan bahwa sumbangan efektif kecanduan game online terhadap empati sebesar $2,26 \%$ sedangkan sisanya $97,74 \%$ ditentukan oleh faktor lain.

\section{Daftar Pustaka}

American Psychiatri Assosiation.. (2013). Diagnostic and Statistical Manual of Mental Disorders Edition "DSM-5". Washington, DC: American Psychiantric Assosiacition. Press.

Baron-Cohen, S., \& Wheelwright, S. (2004). The Empati Question: An Investigation Of Adult With Asperger Syndrome Or High Functioning Autism, And Normal Sex Differences. Journal Of Autism And Developmental Disorder, 34, 2, 163-175.

Batson, C.D., \& Ahmad, Y.N., (2009) Using Empathy to Improve Intergroup Atitudes and Relations, the Psychology Study of Sicia Issues, Vol.3, 141-177.

Baron, R.A\& Byrne, D. (2003). Psikologi Sosial (Edisi Kesepuluh). Jakarta: Erlangga

Batson, C. D., Eklund, J. H., Chermok, V. L., Hoyt, J. L., \& Ortiz, B. G. (2007). An additional antecedent of empathic concern: Valuing the welfare of the person in need. Journal of Personality And Social Psychology, 93(1), 65 Blais, J. J., Craig, W.M., Pepler, D., Connoly, J. (2007). Adolescentsonline: The Importance of Internet Activity Choices To Salient Relationships. J Youth 
Adolescence (2008) 37:522-536

Borba, M. (2008). Membangun Kecerdasan Moral. Jakarta: Gramedia Utama

Chen, C.-Y., \& Chang, S.-L. (2008). An Exploration Of The Tendency To Online Game Addiction Due To User's Liking Of Design Features. Asian Journal Of Health And Information Sciences, 3, 38-51.

Chou, C., Condron, L., \& Belland, J. C., (2005). A Review of the Research on Internet Addiction. Educational Psychology RReview. Vol.17 No. 4.p: 363-387

Chou, C., \& Hsiao, M.-C. (2000). Internet Addiction, Usage, Gratification, And Pleasure Experience: The Taiwan College Students' Case. Computers \& Education, $35,65-80$.

Eisenberg, N. (2000). Emotion, Regulation, and Moral Development. Annual Review Psychology. Department of Psychology, Arizona State University, Tempe, Arizona 85287-1107.

Fauzi, A.D. (2015). Hubungan Intensitas Penggunaan Situs Jejaring Sosial Dengan Empati Pada Remaja. Skripsi. Fakultas Psikologi Universitas Islam Negeri Sulthan Syarif Kasim Riau.

Ferdy.M (2014). Hubungan Kecanduan Bermain Game Online dengan Konpetensi Sosial Pada Remaja. Skripsi. Fakultas Psikologi Universitas Islam Negeri Sultan Syarif Kasim Riau.

Fitri, A. R \& Widiningsih, Y. (2016). Psikologi Kecanduan. Pekanbaru: Al Mujtahadah Press.

Freeman, C. B. (2010). Internet Gaming Addiction. The Journal For Nurse practitioners-JNP. American College of Nurse Pratitioners. Doi:10.1016/j. nupra.2007.10.006.

Gerry F. Kapoh, (2015), Perilaku Sosial Individu Pemain Game Online "Perfect World, Di Desa Sea Satu, Jurnal Holistik Tahun VIII No. 15 / Januari - Juni 2015

Ghodse, H. (2002). Drugs And Addictive Behavior. A Guide To Treatment. Third Edition. Cambridge: Cambridge University Press

Goleman, D. (2007). Emotional Intelligence. Jakarta: Gramedia Pustaka Utama.

Griffiths, M. (1995). Technological Addiction. Clinical Psikology Forum 76, 14-19
(2007). Internet Psychology,

A Very Personal Reflection : Review Of The Oxford Handbook Of Internet Psychology, Edited Bf A, N, Joinsen K.Y A. Mckenna, T. Potsmes And U.-D. Reips, Internasional Journal Internet Science Oxford University Press,

Hoffman, M.L. (2000). Empathy And Moral Development: Implications For Caring And Justice. Cambridge University Press.

Hornby, A. S. (2000). Oxford Advanced Learner"s Dictionary.New York : Oxford University Press.

Imanuel, N. (2009). Gambaran Profil Kepribadian Remaja Yang Kecanduan Game Online Dan Tidak Kecanduan Game Online. Skripsi. Dipublikasikan. Depok: Fakultas Psikologi Universitas Indonesia.

Kandell, J. J, (1998), Internet Addiction On Campus: The Vulnerability Of College Students, Cyberpsychology \& Behavior Volume 1, Number 1

Kaplan, A. M., and Haenlein, Michael, (2010), Users of the world, unite! The challenges and opportunities of Social Media, Business Horizons 53: 59-68

Keen S (2007). Empathy and the Novel. Oxford University Press

Kuss, D.J., \& Griffiths, M.D. (2012). Online gaming Addiction in children and adolescents: A review of empirical research. Journal of behavioral addiction. $1,(1), 1-20$

Kusumadewi, T. N (2009). Hubungan Antara Kecanduan Game Online Dengan Keterampilan Sosial Pada Remaja (Relations Between Internet Game Online And Social Skills In Adolescents) Skripsi. Fakultas Psikologi Universitas Indonesia.

Madina, (2014). Landasan dasar bimbingan dan konseling untuk membangun empati mahasiswa. Skripsi. Fakultas Psikologi Universitas Gorontalo.

Nasrullah, Rulli, (2001), Komunikasi Antar Budaya di Era Budaya Siber . Jakarta: kencana Prenada Media Group

Nurhayati, (2012), hubungan empati dengan perilaku sosial pada mahasiswa baru. Skripsi. Fakultas Psikologi Universitas Muhammadiyah malang.

Purnomo, A. (2014). Hubungan Antara 
Kecanduan Gadget (Mobile Phone) dengan Empati pada Mahasiswa. Skripsi Fakultas IImu Sosial Dan Humaniora Uin Sunan Kalijaga Yogyakarta.

Pratiwi, C.P. (2012). Perilaku Kecanduan Game Online Ditinjau dari Efikasi Diri Akademik dan Ketempilam Sosial Pada Remaja Disurakarta. Jurnal . Surakarta: Program Studi Psikologi Universita Sebelas Maret.

Prayoga, B. (2009). Hubungan antara kontrol diri dengan kecanduan Game Online. Skripsi. Surakarta : Fakultas Psikologi Universitas Muhammadiyah.

Saputra, (2016). Peran Komunitas Mobil Offroad Skin Terhadap Kepedulian Sosial Masyarakat Di Kelurahan Sumberejo Kota Bandar Lampung. Skripsi. Fakultas Keguruan Dan IImu Pendidikan Universitas Bandar Lampung.

Setyawan I. (2001). Peran Kemampuan Empati pada Efikasi Diri Mahasiswa Peserta Kuliah Kerja Nyata Ppm Posdaya. Proceeding Konferensi Nasional II Ikatan Psikologi Klinis - Himpsi. Hal. 296-300.

W. Setiawan, (2013) The Development and Use of Cyber Learning School Community (CLSC) Application to Build Learning Community, Journal of Information Engineering and Applications, 2013.

Siswoyo, Dwi dkk. (2007). Ilmu Pendidikan. Yogyakarta: UNY Press

Soetjipto. (2007). Berbagai Macam Adiksi Dan Penataletaknya. Anima : Indonesia. Psychology Journal. Vol 23. No.1.P:84-90.

Smahel, D., Brown, B. B., \& Blinka, L, (2012), Associations between Online Friendship and InternetAddiction among Adolescents and Emerging Adults, Developmental Psychology 48 (2) : 381-288.

Suler, J. (1996). Computer and Cyberspace Addiction (Online). Rider University. Available at http://www1.Rider.edu/ suler/ psycyber/psycyber.html

Straubhaar, J., LaRose, R., and Davenpo, L, (2010), Media Now: Understanding Media, Culture, and Technology, 7th edition, Wadsworth, Cengage Learning, United States of America

Taufik. (2012). Empati Pendekatan Psikologi Sosial. Jakarta : Rajawali Pers

Theodora, (2012). Hubungan Antara
Kecanduan Internet Game Online danKeterampilan Sosial pada Remaja (Relation Between Internet Game Online Addiction andSocial Skills in Adolescents). Fakultas Psikologi Universitas Indonesia Weinstein, A. M. (2010). Computer and Video Game Addiction - A Comparison Between Game Users And Non Game Users. The American Journal Of Drug And Alcohol Abuse, 36, 268-276. Doi:10.3109/009529 90.2010.491879 (Diakses Oktober 2016).

Yee, N. (2002). Ariadne: Understanding Mmorpg Addiction http ://Www. Nickyee. Com /Hub /Addiction/Pdf

Young, K. (2009). Understanding Online Gaming Addiction And Treatment Issues For Adolescents. The American Journal Of Family Therapy, 37, 355-372. . )1998). The Relationship between Depression and Internet Addiction. Cyber Psychology and Behavior 1 (1) 25-28 